\title{
Investigating the significance of Caring School Leadership (CSL) in Mediating Psychosocial Safety Climate (PSC) and Associated Health Outcomes for Teachers in South African Primary and Secondary Schools
}

\author{
Peter Winwood ${ }^{1}$ and Liezl Kramer ${ }^{2}$ \\ ${ }^{1}$ School of Psychology, Social Work \& Social Policy,University of South Australia, Australia \\ ${ }^{2}$ Royal Holloway, University of London School of Management, England
}

Submission: September 30, 2020; Published: November 23, 2020

*Corresponding author: Peter Winwood,BDS, BPsyc. (Hons), PhD,School of Psychology, Social Work \& Social Policy, University of South Australia, Australia

\begin{abstract}
Suboptimal levels of psychosocial working conditions within schools, associated with high levels of dysfunctional outcomes for teachers are increasingly reported worldwide.This study examines the issue within a cohort of 664 South African (SA) primary and secondary school teachers at both private and government schools, from both rural and urban areas in 7 South African provinces. Consistent with the principle of Psychosocial Safety Climate (PSC) as a 'top down' phenomenon within organizations, we focus on the critical role and capacity of the school leader, or principal, as a Caring School Leader (CSL) in building and maintaining high PSC values which moderate the evolution of preventable maladaptive work-related stress and its negative outcomes for teachers. It is the first empirical study to investigate the stress experience of SA teachers, which we assert is an exemplar of an approach to addressing problems of poor Engagement, low Morale, Cynicism, Persistent Fatigue, Work Related Poor Health and Absenteeism within the teaching profession.
\end{abstract}

Keywords: Psychosocial, Caring School Leader, Absenteeism, Psychological health problems, Psychosocial hazards, Behaviours.

\section{Introduction}

Poor psychological health and associated maladaptive health outcomes in the workplace are an increasing problem worldwide, associated with significant social and economic costs [1] and an annual reduction in productivity [2]. Within this context, teaching ranks amongst the most stressful professions globally. Frequently, teachers are reported to experience career-compromising levels of stress, burnout and maladaptive health outcomes [3-7]. This situation is well known to exist within South African (SA) schools $[8,9]$. Given the high costs of work-related psychological health problems, Cox et al. [10] argue that adequate measures to identify, assess and manage psychosocial hazards in the workplace are essential both for the good of the individual and the overall good of the organisation. However, to date the phenomenon has been little studied or researched empirically.

Following a study into institutional environments, Australian and Dutch organisation psychologists have proposed the construct of Psychosocial Safety Climate (PSC) as an overarching explanation of work stress [11]. They posited that PSC encompassed the management philosophies, policies, processes and practices, through and by which workers perceived that they were safe (BOTH physically and emotionally) at work and that their work was valued [12]. PSC is conceptualised as a broader concept than the (physical) simple safety climate construct. In addition to the physical health and safety considered by Zohar [13]. PSC has a broader focus, which includes the psychological and emotional safety of workers. This includes safety from bullying and harassment (physical, emotional and sexual), as well as freedom from unfair or unreasonable work demands, arbitrary dismissal and intimidation. The PSC construct argues that, taken together, the many elements that come together in the workplace constituted a 'climate'. Like any climate, PSC affects all who are subjected to it directly, or otherwise experience it indirectly. For example, bullying may not only have an adverse effect on 
the individual, but also on those who witness such bullying, particularly when it is seen to go unchecked. Importantly, PSC recognises that this climate is not arbitrary, but is specifically dependent on those in the workplace who have the discretionary authority to enable and maintain it. Consequently, PSC is seen as an essentially 'top-down', management-driven organisational phenomenon [1].

Hence, Dollard et al. [14] propose that the interaction of workplace resources and demands really depends on high levels of PSC as an essential enabler for the utilisation of available resources to reduce job demands, thereby setting a trajectory either towards health and engagement, or alternatively, towards health problems, dysfunctional attitudes and maladaptive behaviours. A key factor of High PSC environments is that they are characterised by leaders (or senior managers) who themselves are committed to minimising work stress and promoting psychological health among employees [1], through the reduction, or at least minimisation, of stress-inducing job experiences. PSC not only serves as a "cause of causes" within an organisation [15], but also both mediates and moderates the extent, level and toleration of important associated workplace behaviour and experience. These include; bullying, overall organisational morale and the regularity of workplace injuries and claims [16]. In turn, such behaviours and experiences are associated with important outcomes, including Absenteeism, Affective Commitment ("I work here because I like it") and Perseverant Commitment ("I only work here because I can't get a better job") and overall Work Engagement [15]. Low PSC is identified as an upstream trigger of workplace bullying, exposure to which ultimately leads to health problems [12], costly outcomes [17] due to increased absenteeism associated with ill health [18], high staff turnover [19] and worker compensation claims [20].

Using the Social Exchange Theory [21], explained the relationship between PSC and Engagement as follows: If employers manifest concern for, and prioritise employee wellbeing, then employees reciprocate by investing their efforts in the job, even when things are not going well, i.e. when there are significant job stressors and available resources may be suboptimal. In the teaching sphere, Garrick et al., [22,23] investigated the prevalence, severity and organisational risk factors for psychological injury in a sample of 960 Australian school teachers. The authors found that teachers at highest risk of psychological injury were working at schools with low levels of PSC. By contrast, higher levels of PSC in schools were found to buffer Australian school teachers from the adverse psychological outcomes associated with the demands of teaching [23]. PSC can thus moderate the effects of daily job demands and daily recovery on teachers' levels of fatigue and work engagement. A comparable situation has been identified in South African schools [8]; notably in primary schools [24]. Others who have focussed a critical eye on the role of the Principal's role in the 21st century school, include Southworth [25] as well as Bush and Glover $[9,26]$. Within the context of PSC development and maintenance, and of particular relevance to the teaching environment, is the work of South African researcher Van der Vyver. He has posited the construct of Caring School Leadership (CSL), to define the extent and degree to which the school principal (and/or management group) actively and deliberatively worked towards creating the environment described in the PSC literature, Van der Vyver et al. (2014).

Until recently, the caring role of the principal toward the teaching staff has been less emphasised. However, it has been shown that the absence of a caring and supportive school principal leads to reduced school effectiveness, reduced teacher commitment and subsequently poor academic performance by learners. These are exactly the predicable effects of suboptimal PSC [27-29]. Hargreaves [30] also identified the importance of a psychologically supportive school management team in ensuring the wellbeing of teaching staff. In this regard, Van der Vyver et al. (2014) recommends the development of a management strategy that focuses on psychological, organisational and management factors to improve the caring role that needs to be played by school principals in SA. Using the principles of the Human Capital Theory , Baptiste (2000), wherein people are regarded as intrinsically valuable assets, the school leadership would thus be tasked with the critical role of transforming schools into caring communities. These are places where teachers experience a positive organisational climate, supporting improved performances by teachers and improved learner outcomes, Van der Vyver et al (2014).

In order to quantify the CSL construct, Van der Vyver developed a 66-item psychometric scale for the measurement of a construct identifying such supportive behaviour on the part of school principals, which they term Caring School Leadership, Van der Vyver et al (2014). Van der Vyver determined the top ten factors contributing towards the establishment of a CSL in SA schools. Five addressed workplace determinants of care (e.g. "My principal sees to a school safety policy."). Four addressed management determinants (e.g. "My principal commits to the vision and mission of the school.") and one addressed psychological determinants of care (i.e. "My principal respects us."

Accordingly, and in the interests of parsimony, these top ten determinants were treated as scale items and combined by the study authors to create a custom designed 10 item psychometric scale to assess CSL, and for use in this study. The items included: "My principal shares successes with teachers"; "My principal sees to a school safety policy"; "My principal limits school vandalism"; "My principal sees to it that buildings are kept in a good condition"; "My principal commits to the vision and mission of 
the school"; "My principal demonstrates self-confidence to lead"; "My principal maintains healthy school discipline"; "My principal respects us"; "My principal provides a safe working environment"; and "My principal works towards the benefit of the whole school community". Thus, whereas the PSC construct examines the work environment broadly, the CSL construct defines and identifies the specific human controlling and maintenance source(s) of the overall school environment assessed by PSC. Significant literature reviews on the challenges facing education and educators generally and within the South African context undertaken by Bush and Glover $[26,27]$ points to the potential value and significance of this approach within the South African context.

Accordingly, the authors tested the following hypotheses in this research study:

i. Hypothesis 1: The level of PSC reported in SA schools will be positively and significantly correlated with the reported level of CSL

ii. Hypothesis 2: Low (Dysfunctional) levels of reported of Affective Commitment, Morale and Work Engagement are negatively related to PSC, and CSL levels.

iii. Hypothesis 3: Reported levels of Bullying, Cynicism, Absenteeism and Work-Affected Poor Health and, Persistent Fatigue will be negatively correlated with reported CSL scores

iv. Hypothesis 4: Low levels of CSL will be associated with higher levels of teacher Abuse by students and/or parents.

\section{Method}

The research method was a single-wave, cross-sectional study using a 104-item questionnaire built on the Qualtrics online platform. This was provided to participants for completion via an email, which contained a live hyperlink to the questionnaire hosted on the Qualtrics site. When completed, the questionnaire was automatically sent to the Qualtrics site for aggregation. The South African provincial Departments of Education were contacted via email, seeking permission to approach their teachers to participate. The various school principals were also asked to endorse and facilitate their teachers' participation by forwarding the email questionnaire link to their teachers. Potential participants received an emailed 'live' hyperlink to the questionnaire. All responses were downloaded in the format of an SPSS data file for analysis. Permission to take part in the study was only received from the following 7 provincial Departments of Education: Eastern Cape; Free State; Gauteng; KwaZulu Natal; Limpopo; Mpumalanga; Western Cape.

\section{Ethics}

Ethical approval for the study was obtained from the University of London. The research was conducted according to internationally accepted guidelines and ethical standards.

\section{Materials}

The study questionnaire comprised a total of 10 subscales that measured key constructs relevant to the study, as detailed in Table 1 (overleaf):

Table 1: Constructs, Scale Items, Number of Items, Emphasis of Scales and Originating Psychometric Scales used in the Study Questionnaire.

\begin{tabular}{|c|c|c|c|c|c|}
\hline & Constructs: & Subscale & $\begin{array}{c}\text { No } \\
\text { items: }\end{array}$ & Scale/Subscale Emphasis & $\begin{array}{c}\text { Originating Psychometric } \\
\text { Scale: }\end{array}$ \\
\hline A & Demographics & ${ }^{*}$ Custom & 12 & Participant Personal Details & ${ }^{*}$ Custom Design \\
\hline B & $\begin{array}{l}\text { School Teaching } \\
\text { Experience } \\
\text { Resources }\end{array}$ & $\begin{array}{l}\text { Caring School Leader- } \\
\text { ship } \\
\text { Cognitive Resources } \\
\text { Emotional Resources }\end{array}$ & $\begin{array}{l}10 \\
4 \\
4\end{array}$ & $\begin{array}{l}\text { Leader commitment to school envi- } \\
\text { ronment } \\
\text { Support for thinking work demands } \\
\text { Support for emotional challenging } \\
\text { work demands }\end{array}$ & $\begin{array}{l}\text { CSL scale (Van de Vyver, } \\
\text { 2014) } \\
\text { Demand Induced Strain } \\
\text { Compensation Questionnaire } \\
\text { (DISCQ) (Bova et al., 2015) }\end{array}$ \\
\hline $\mathrm{C}$ & $\begin{array}{l}\text { Psychological Health } \\
\text { and Safety Climate }\end{array}$ & PSC-12 & 12 & $\begin{array}{c}\text { The extent to which work environment } \\
\text { is both supportive and protective of } \\
\text { worker health including psychological } \\
\text { health }\end{array}$ & PSC-12 (Hall et al., 2010) \\
\hline $\mathrm{D}$ & Attitudes to Work & $\begin{array}{l}\text { Affective Commitment } \\
\text { Perseverant Commit- } \\
\text { ment } \\
\text { Bullying } \\
\text { Morale }\end{array}$ & $\begin{array}{l}4 \\
4 \\
5 \\
6\end{array}$ & $\begin{array}{c}\text { "I work here because I like it" } \\
\text { “I only work here because I can’t get a } \\
\text { better job." } \\
\text { Experience or observation of work- } \\
\text { place bullying } \\
\text { Worker feeling of positivity \& hope- } \\
\text { fulness }\end{array}$ & $\begin{array}{c}\text { Organisational Commitment } \\
\text { Scale (Meyer and Allen, } \\
\text { 1991) } \\
\text { Organisational Psychosocial } \\
\text { Risk Indicator (Winwood et } \\
\text { al., 2013) }\end{array}$ \\
\hline
\end{tabular}




\section{Psychology and Behavioral Science International Journal}

\begin{tabular}{|c|c|c|c|c|c|}
\hline $\mathrm{E}$ & Feelings at Work & $\begin{array}{c}\text { Engagement } \\
\text { Cynicism }\end{array}$ & 4 & $\begin{array}{l}\text { Worker feeling of positive attitude to } \\
\text { work and workplace } \\
\text { Worker doubt of the meaningfulness of } \\
\text { their work activity and effort }\end{array}$ & $\begin{array}{c}\text { Utrecht Work Engagement } \\
\text { Survey (UWES) (Schaufeli } \\
\text { and Bakker, 2006) } \\
\text { Maslach Burnout Inventory } \\
\text { (MBI) General Scale (Maslach } \\
\text { et al., 1981) }\end{array}$ \\
\hline $\mathrm{F}$ & $\begin{array}{c}\text { Effect of Work on } \\
\text { Health } \\
\text { Fatigue/Depression } \\
\text { Daily Fatigue } \\
\text { Energy Recovery }\end{array}$ & $\begin{array}{l}\text { Work related Health } \\
\text { problems } \\
\text { OFER-CF Chronic } \\
\text { Fatigue } \\
\text { OFER-AF Acute Fatigue } \\
\text { OFER-IR Recovery } \\
\text { Absenteeism }\end{array}$ & $\begin{array}{l}5 \\
5 \\
5\end{array}$ & $\begin{array}{c}\text { Reported health problems associated } \\
\text { with work } \\
\text { Fatigue not recovered by adequate rest } \\
\text { or task moderation } \\
\text { End of workday fatigue } \\
\text { Recovery of energy between work } \\
\text { shifts } \\
\text { Absence from work without acceptable } \\
\text { reason or excuse }\end{array}$ & $\begin{array}{c}\text { Organisational Psychosocial } \\
\text { Risk Indicator (Winwood et } \\
\text { al., 2013) } \\
\text { Occupational Fatigue, Ex- } \\
\text { haustion Recovery (OFER) } \\
\text { Scale (Winwood et al., 2006) } \\
\text { Organisation Psychosocial } \\
\text { Risk Indicator (Winwood et } \\
\text { al., 2013) }\end{array}$ \\
\hline
\end{tabular}

Results

A total of 664 teachers completed the Qualtrics-hosted study survey via the hyperlink sent to them by email. Table 2 reports the demographic details of all 664 respondents according to gender, age, teaching experience, tenure, school location and type.

Table 2: Participant Demographics: ALL, Gender, Age, Experience, Tenure, Location and School Type at Time of the Study

\begin{tabular}{|c|c|c|c|c|c|c|}
\hline $\begin{array}{l}\text { Gender } \\
\text { n (\%): }\end{array}$ & $\begin{array}{l}\text { Mean Age } \\
\text { (SD): }\end{array}$ & $\begin{array}{c}\text { Mean Years of } \\
\text { Experience (SD): }\end{array}$ & $\begin{array}{l}\text { Mean Years of } \\
\text { Tenure (SD): }\end{array}$ & $\begin{array}{c}\text { Rural/ Urban } \\
\text { n(\%): }\end{array}$ & $\begin{array}{c}\text { Private/ Government } \\
\text { n (\%): }\end{array}$ & $\begin{array}{c}\text { Primary /Secondary } \\
\text { n (\%): }\end{array}$ \\
\hline $\begin{array}{c}\text { Female } \\
471 \\
(71.0 \%)\end{array}$ & $\begin{array}{l}41.3 \text { yrs } \\
(\text { SD } 12.5)\end{array}$ & $\begin{array}{l}16.7 \mathrm{yrs} \\
(\mathrm{SD} 12.8)\end{array}$ & $\begin{array}{l}8.8 \text { yrs } \\
\text { (SD 8.9) }\end{array}$ & $\begin{array}{c}\text { Rural } \\
93 \\
(19.7 \%) \\
\text { Urban } \\
378 \\
(80.3 \%)\end{array}$ & $\begin{array}{c}\text { Private } \\
54 \\
(11.5 \%) \\
\text { Government } \\
417 \\
(88.5 \%) \\
\end{array}$ & $\begin{array}{c}\text { Primary } \\
269 \\
(57.1 \%) \\
\text { Secondary } \\
202 \\
(42.9 \%)\end{array}$ \\
\hline $\begin{array}{c}\text { Male } \\
193 \\
(29.0 \%)\end{array}$ & $\begin{array}{l}\text { 45.1yrs } \\
\text { (SD 12.5) }\end{array}$ & $\begin{array}{l}20.5 \text { yrs } \\
(S D 13.1)\end{array}$ & $\begin{array}{l}10.9 \text { yrs (SD } \\
9.7)\end{array}$ & $\begin{array}{c}\text { Rural } \\
56 \\
(29.0 \%) \\
\text { Urban } \\
137 \\
(71.0 \%) \\
\end{array}$ & $\begin{array}{c}\text { Private } \\
12 \\
(6.2 \%) \\
\text { Government } \\
181 \\
(93.8 \%)\end{array}$ & $\begin{array}{c}\text { Primary } \\
89 \\
(46.1 \%) \\
\text { Secondary } \\
104 \\
(53.9 \%)\end{array}$ \\
\hline $\begin{array}{l}\text { ALL } \\
664\end{array}$ & $\begin{array}{l}43.2 \text { yrs } \\
\text { (SD 12.5) }\end{array}$ & $\begin{array}{l}18.6 \text { yrs } \\
(S D 13.0)\end{array}$ & $\begin{array}{l}9.85 \text { yrs } \\
\text { (SD 9.1) }\end{array}$ & $\begin{array}{c}\text { RURAL } \\
149 \\
(22.5 \%) \\
\text { URBAN } \\
(77.5 \%)\end{array}$ & $\begin{array}{c}\text { PRIVATE } \\
66 \\
(9.9 \%) \\
\text { GOVNT } \\
(90.1 \%)\end{array}$ & $\begin{array}{c}\text { PRIMARY } \\
(54 \%) \\
\text { SECONDARY } \\
(46 \%)\end{array}$ \\
\hline
\end{tabular}

Table 3: Distribution of PSC Scores According to Respondent Age and Teaching Experience.

\begin{tabular}{|c|c|c|c|}
\hline Age Level (Years) & Experience Level (Years) & $\mathbf{N}$ & PSC Mean Score \\
\hline \multirow{2}{*}{$1(18-25)$} & $1(1-5)$ & 55 & 27.88 \\
\hline & $2(6-10)$ & 1 & 13.33 \\
\hline \multirow{2}{*}{$2(26-31)$} & $1(1-5)$ & 95 & 21.21 \\
\hline & $2(6-10)$ & 33 & 30.65 \\
\hline \multirow{3}{*}{$3(32-40)$} & $1(1-5)$ & 17 & 25.24 \\
\hline & $2(6-10)$ & 60 & 23.38 \\
\hline & $3(13-20)$ & 46 & 23.75 \\
\hline \multirow{4}{*}{$4(41-50)$} & $1(1-5)$ & 7 & 14.52 \\
\hline & $2(6-10)$ & 19 & 22.45 \\
\hline & $3(13-20)$ & 33 & 23.03 \\
\hline & $4(21-30)$ & 90 & 29.90 \\
\hline
\end{tabular}




\section{Psychology and Behavioral Science International Journal}

\begin{tabular}{|l|c|c|c|}
\hline \multirow{3}{*}{$5(51-70)$} & $2(6-10)$ & 1 & 30.00 \\
\cline { 2 - 4 } & $3(13-20)$ & 9 & 31.94 \\
\cline { 2 - 4 } & $4(21-30)$ & 44 & 32.40 \\
\cline { 2 - 4 } & $5(31-45)$ & 152 & 33.22 \\
\hline
\end{tabular}

As evident in Table 2, most of the teachers were female $(71 \%$ vs $29 \%$ ), with a mean age of more than 40 years. The mean years of teaching experience was 16.7 years for women and 20.5 years for men. The mean years of tenure was 8.8 years for women and 10.9 years for men. In sum, the respondents were predominantly middle-aged, mature and experienced. This was considered as potentially significant because it could suggest that, whilst their reports are more likely to be reflective of a considered judgment based on extensive knowledge of their schools, it could also indicate a biased sample of 'jaded' or potentially burned out teachers. This possibility was investigated further. PSC scores were assessed according to respondent Age Level and Teaching Experience. Table 3 reports the results of this investigation.

Examination of respondent report of PSC mean scores according to Age Level and Teaching Experience shown in Table 3 , does not indicate any consistent age-related bias in reporting of PSC indicative of an 'older worker' burnout biasing. Rather the poorer mean scores are reported by the younger and/or less experienced teacher respondents.

Table 4, below, reports the Pearson r Bivariate Correlations (two-tailed) between all study variables.

Table 4: Pearson Bivariate Correlations Two Tailed Between Study Variables.

\begin{tabular}{|c|c|c|c|c|c|c|c|c|c|c|c|c|c|c|c|c|c|}
\hline & PSC & CSL & $\begin{array}{l}\text { Bul- } \\
\text { ly- } \\
\text { ing }\end{array}$ & $\begin{array}{l}\text { Mo- } \\
\text { rale }\end{array}$ & $\begin{array}{l}\text { Per- } \\
\text { sistent } \\
\text { Fa- } \\
\text { tigue }\end{array}$ & $\begin{array}{l}\text { Acute } \\
\text { Fa- } \\
\text { tigue }\end{array}$ & $\begin{array}{l}\text { Chron- } \\
\text { ic Fa- } \\
\text { tigue }\end{array}$ & $\begin{array}{c}\text { Ab- } \\
\text { sent'ism }\end{array}$ & $\begin{array}{l}\text { Work } \\
\text { Affect- } \\
\text { ed Poor } \\
\text { Health }\end{array}$ & $\begin{array}{l}\text { Affec- } \\
\text { tive } \\
\text { Com- } \\
\text { mit- } \\
\text { ment }\end{array}$ & $\begin{array}{l}\text { Perse- } \\
\text { verant } \\
\text { Com- } \\
\text { mit- } \\
\text { ment }\end{array}$ & $\begin{array}{l}\text { Cogni- } \\
\text { tive Re- } \\
\text { sources }\end{array}$ & $\begin{array}{l}\text { Emo- } \\
\text { tional } \\
\text { Re- } \\
\text { sourc- } \\
\text { es }\end{array}$ & $\begin{array}{l}\text { Physi- } \\
\text { cal Re- } \\
\text { sourc- } \\
\text { es }\end{array}$ & $\begin{array}{l}\text { En- } \\
\text { gage- } \\
\text { ment }\end{array}$ & $\begin{array}{l}\text { Phys- } \\
\text { ical } \\
\text { Abuse }\end{array}$ & $\begin{array}{l}\text { Ver- } \\
\text { bal } \\
\text { Abuse }\end{array}$ \\
\hline PSC & 1.00 & & & & & & & & & & & & & & & & \\
\hline $\begin{array}{c}\text { Caring } \\
\text { School } \\
\text { Lead- } \\
\text { ership } \\
\text { (CSL) }\end{array}$ & .63 & 1.00 & & & & & & & & & & & & & & & \\
\hline $\begin{array}{c}\text { Bully- } \\
\text { ing }\end{array}$ & -.63 & -.61 & 1.00 & & & & & & & & & & & & & & \\
\hline Morale & .69 & .72 & -.70 & 1.00 & & & & & & & & & & & & & \\
\hline $\begin{array}{c}\text { Per- } \\
\text { sistent } \\
\text { Fatigue }\end{array}$ & -.52 & -.34 & .45 & -.45 & 1.00 & & & & & & & & & & & & \\
\hline $\begin{array}{l}\text { Acute } \\
\text { Fatigue }\end{array}$ & -.47 & -.30 & .41 & -.42 & .69 & 1.00 & & & & & & & & & & & \\
\hline $\begin{array}{l}\text { Chronic } \\
\text { Fatigue }\end{array}$ & -.57 & -.44 & .56 & -.54 & .71 & .68 & 1.00 & & & & & & & & & & \\
\hline $\begin{array}{l}\text { Absen- } \\
\text { teeism }\end{array}$ & -.24 & -.34 & .27 & -.35 & .20 & .12 & .29 & 1.00 & & & & & & & & & \\
\hline $\begin{array}{c}\text { Work } \\
\text { Affect- } \\
\text { ed Poor } \\
\text { Health }\end{array}$ & -.41 & -.33 & .47 & -.40 & .54 & .54 & .69 & .29 & 1.00 & & & & & & & & \\
\hline $\begin{array}{l}\text { Affec- } \\
\text { tive } \\
\text { Com- } \\
\text { mit- } \\
\text { ment }\end{array}$ & .61 & .67 & -.60 & .71 & -.47 & -.41 & -.61 & -.36 & -.44 & 1.00 & & & & & & & \\
\hline $\begin{array}{c}\text { Perse- } \\
\text { verant } \\
\text { Com- } \\
\text { mit- } \\
\text { ment }\end{array}$ & -.56 & -.57 & .54 & -.61 & .47 & .39 & .63 & .36 & .45 & -.75 & 1.00 & & & & & & \\
\hline
\end{tabular}




\section{Psychology and Behavioral Science International Journal}

\begin{tabular}{|c|c|c|c|c|c|c|c|c|c|c|c|c|c|c|c|c|c|}
\hline $\begin{array}{l}\text { Cogni- } \\
\text { tive Re- } \\
\text { sources }\end{array}$ & .49 & .42 & -.45 & .44 & -.38 & -.41 & -.45 & -.17 & -.34 & .48 & -.40 & 1.00 & & & & & \\
\hline $\begin{array}{c}\text { Emo- } \\
\text { tional } \\
\text { Re- } \\
\text { sources }\end{array}$ & .64 & .54 & -.65 & .69 & -.42 & -.42 & -.52 & -.31 & -.41 & .65 & -.54 & .61 & 1.00 & & & & \\
\hline $\begin{array}{l}\text { Physi- } \\
\text { cal Re- } \\
\text { sources }\end{array}$ & .47 & .52 & -.43 & .52 & -.26 & -.26 & -.35 & -.28 & -.29 & .59 & -.47 & .42 & .50 & 1.00 & & & \\
\hline $\begin{array}{l}\text { En- } \\
\text { gage- } \\
\text { ment }\end{array}$ & .47 & .49 & -.47 & .52 & -.54 & -.40 & -.63 & -.36 & -.43 & .69 & -.60 & .40 & .50 & .36 & 1.00 & & \\
\hline $\begin{array}{l}\text { Phys- } \\
\text { ical } \\
\text { Abuse }\end{array}$ & -.18 & -.17 & .27 & -.21 & .16 & .17 & .23 & .08 & .27 & -.23 & .25 & -.19 & -.24 & -.23 & -.17 & 1.00 & \\
\hline $\begin{array}{l}\text { Verbal } \\
\text { Abuse }\end{array}$ & -.31 & -.25 & .45 & -.32 & .30 & .31 & .43 & .10 & .41 & -.34 & .34 & -.28 & -.36 & -.24 & -.29 & .34 & 1.00 \\
\hline
\end{tabular}

The correlations reported in Table 4 reveal a notable similarity for PSC and CSL reports. Indeed, it suggests that, at least in the teaching context, PSC and CSL are virtually synonymous. It also indicates that the CSL scale is addressing the specific management drivers of the perceived climate. Both constructs are strongly positively correlated with Morale, Resources, Affective Commitment and strongly negatively correlated to Bullying, Perseverant Commitment, Fatigue and Staff Abuse constructs. This is fully consistent with the central tenant of PSC, i.e. that is a 'top down' phenomenon. The CSL scale personalises this to the 'leader' of the school, namely the Principal whose direct and supportive involvement with staff leads to high PSC development. The correlations reported here are fully consistent with the expectations of Hypothesis 1, 2, 3 and 4.

The PSC/CSL relationship was further examined for mediating factors between the two. Figure 1 below reports a Sobel test of Mediation and indicated that the effect of CSL on PSC was fully mediated through the construct of Morale as anticipated.

\section{Mediating Effect of Morale on Relationship Between CSL and PSC among South African Teachers}

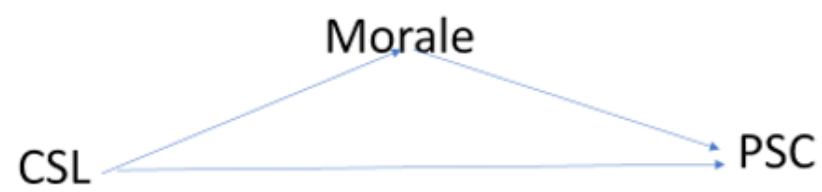

\section{$Z$ (Sobel Statistic) $=7.95 p=.000$}

Figure1: Sobel Test of meditation of morale between CSL and PSC.

This indicates (unsurprisingly) that the effective caring school Principal has a direct effect on the Morale within the school, thereby lifting the PSC overall. For ease of categorising PSC scores in terms of anticipatable Health Risk to workers, Bailey has identified PSC scores $\leq 37$ as conferring a HIGH risk to worker health; scores 37.1-40.9 as conferring MODERATE risk, and scores $\geq 41$ as conferring LOW risk to worker health [35]. Examining the study cohort PSC levels further, Table 5 reports PSC scores relative to corresponding CSL levels, and corresponding scores on key work experience constructs of Bullying, Engagement and Absenteeism.

The values reported in Table 5 are again fully consistent with and supportive of Hypotheses 1 and 3. Low CSL values in a school 


\section{Psychology and Behavioral Science International Journal}

are associated with poor PSC where high levels of bullying are evident, with lower teacher Engagement and higher incidence of Absenteeism.
Further examination of PSC and CSL scores distribution according to whether participants taught, in Private or Government schools, was undertaken and is reported in Table 6.

Table 5: Variation in PSC, Bullying, Engagement and Absenteeism Rates According to CSL Level.

\begin{tabular}{|c|c|c|c|c|}
\hline CSL Level & $\begin{array}{l}\text { PSC (Bailey) } \\
\text { Mean Score }\end{array}$ & $\begin{array}{c}\text { Bullying } \\
\text { Mean Score }\end{array}$ & $\begin{array}{l}\text { Engagement } \\
\text { Mean Score }\end{array}$ & $\begin{array}{l}\text { Absenteeism } \\
\text { Mean Score }\end{array}$ \\
\hline LOW (0-25) & 6.2 & 72.0 & 52.0 & 28.5 \\
\hline Moderate High (51-75) & 19.8 & 56.5 & 67.8 & 18.3 \\
\hline HIGH (76-100) & 38.8 & 32.5 & 79.5 & 10.6 \\
\hline
\end{tabular}

Table 6: t-Test Comparisons of Mean Factor Scores: Government vs Private Schools.

\begin{tabular}{|c|c|c|c|c|}
\hline \multirow{2}{*}{ Factor } & Government Schools Mean & Private Schools Mean & \multirow{2}{*}{ t-value of Difference in Mean } & \multirow{2}{*}{$p$ value } \\
\hline & $n=598$ & $n=66$ & & \\
\hline PSC & 27.38 & 30.35 & -4.2 & $\mathbf{0}$ \\
\hline CSL & 74.4 & 80.2 & -8.5 & $\mathbf{0}$ \\
\hline Morale & 58.8 & 68.5 & -9.28 & $\mathbf{0}$ \\
\hline Emotional Resources & 61.96 & 70.8 & -8.05 & $\mathbf{0}$ \\
\hline Physical Resources & 54.9 & 65.4. & -8.23 & $\mathbf{0}$ \\
\hline Work Affected Poor Health & 36.7 & 29.9 & 6.92 & $\mathbf{0}$ \\
\hline Engagement & 72.7 & 78 & -6.24 & $\mathbf{0}$ \\
\hline
\end{tabular}

Of interest, the reported values for both PSC and CSL in Private Schools was higher than Government Schools. Similarly, the scores of all the associated work experience and behaviours were better, i.e. higher Morale, Resources, Engagement and lower Work Affected Poor Health.

\section{Teacher abuse}

The abuse of teachers in their workplace, physically or verbally, is a significant matter likely to impact directly on their health and decisions to continue within the profession. Respondents were asked to report on how frequently their experience of either of these events ranged between Insignificant $(=1)$ to Serious $(=3)$. Table 7 reports the distribution of these values by school type and location.

Table 7 indicates a notable level of both Verbal and Physical Abuse is experienced by teachers in Government Secondary schools compared with other types. There is little difference in this phenomenon between Urban or Rural locations. The pattern of Verbal Abuse is also evident in Primary schools, although the pattern of Physical Abuse is very low, perhaps because of the smaller size of such students. The comparatively low report of any abuse of teachers in Private schools is not entirely unexpected, given that such schools have (usually) the capacity to expel any unruly or difficult students (or parent) much more readily than Government schools.

Table 7: Distribution of Teacher Abuse (Verbal and Physical) by School Location and Type: $\mathrm{N}$ and \% and Location Total.

\begin{tabular}{|c|c|c|c|c|c|c|c|}
\hline \multicolumn{4}{|c|}{ Verbal Abuse } & \multicolumn{4}{|c|}{ Physical Abuse } \\
\hline \multirow{3}{*}{ Location } & $\mathbf{N}$ & $\mathbf{N}$ & $\mathbf{N}$ & \multirow{3}{*}{ Location } & $\mathbf{N}$ & $\mathbf{N}$ & $\mathbf{N} /$ \\
\hline & (\%) & $\%$ & $\%$ & & $\%$ & $\%$ & $\%$ \\
\hline & Not Significant & Challenging & Serious & & Not Significant & Challenging & Serious \\
\hline $\mathrm{N}=664$ & 399 & 61 & \multirow{2}{*}{$20430.8 \%$} & \multirow{2}{*}{ OVERALL } & 634 & 9 & 21 \\
\hline OVERALL & $60 \%$ & $9.20 \%$ & & & $95 \%$ & $1.40 \%$ & $3.60 \%$ \\
\hline $\mathrm{N}=359$ & 253 & 56 & 50 & \multirow{2}{*}{ N=501 Urban } & 470 & 25 & 6 \\
\hline Urban & $49.10 \%$ & $10.90 \%$ & $9.70 \%$ & & $93.80 \%$ & $4.90 \%$ & $1.20 \%$ \\
\hline
\end{tabular}




\section{Psychology and Behavioral Science International Journal}

\begin{tabular}{|c|c|c|c|c|c|c|c|}
\hline $\mathrm{N}=101$ & 70 & 20 & 11 & $\mathrm{~N}=142$ & 134 & 5 & 32. \\
\hline Rural & $69.30 \%$ & $19.80 \%$ & $10.90 \%$ & Rural & $94.40 \%$ & $3.50 \%$ & $2 \%$ \\
\hline$N=598$ & 348 & 57 & \multirow{2}{*}{$19332.3 \%$} & $N=598$ & 568 & 9 & 21 \\
\hline Govt & $58.20 \%$ & $9.50 \%$ & & Govt & $95 \%$ & $1.50 \%$ & $3.50 \%$ \\
\hline \multirow{2}{*}{$\mathrm{N}=55$ Private } & 49 & 2 & 4 & \multirow{2}{*}{ Private } & 65 & 1 & 0 \\
\hline & $89.10 \%$ & $3.60 \%$ & $7.30 \%$ & & $98.50 \%$ & $1.50 \%$ & $0 \%$ \\
\hline \multirow{2}{*}{$\begin{array}{l}\mathrm{N}=306 \mathrm{Sec}- \\
\text { ondary }\end{array}$} & 167 & 21 & \multirow{2}{*}{$11838.6 \%$} & \multirow{2}{*}{$\begin{array}{c}\mathrm{N}=306 \text { Second- } \\
\text { ary }\end{array}$} & 288 & 5 & 13 \\
\hline & $54.60 \%$ & $6.90 \%$ & & & $94.10 \%$ & $1.60 \%$ & $4.20 \%$ \\
\hline $\mathrm{N}=358$ & 232 & 40 & 86 & \multirow{2}{*}{$N=358$ Primary } & \multirow{2}{*}{$346 / 96.6 \%$} & 4 & 8 \\
\hline Primary & $64.80 \%$ & $11.20 \%$ & $24 \%$ & & & $1.10 \%$ & $2.20 \%$ \\
\hline
\end{tabular}

Notes: Notably High Scores have been bolded, Notably Low figure are highlighted in Red.

Score of 1 on assessment scale was graded as 'Insignificant', score 2 reflected 'Challenging' and 3 reflected 'Serious' abuse experience.

Figure 2 indicates the reports of teacher abuse depending on the level of CSL reported at the various school types and locations.

Both Table 7 and Figure 2 confirm the expectations of Hypothesis 4. Figure 2 indicates that the higher the CSL level within the school, the lower the level of verbal abuse. Figure 2 reports the comparable relationship of abuse with PSC levels. The correspondence of Figures is notable but not surprising given the high correlation between the constructs shown in Table 4. Physical abuse (overall) is evidently a lesser problem, not exceeding 5.8\% (secondary schools) for 'challenging and serious' levels combined. Also, of interest is the observation that the positive effect of CSL on Teacher Abuse does not manifest until the value of CSL is at higher levels. This would be consistent with the notion that such dysfunctional behaviour within the student/parent body requires a more significant influence from the Principal before it manifests in change/reduction of such behaviours.

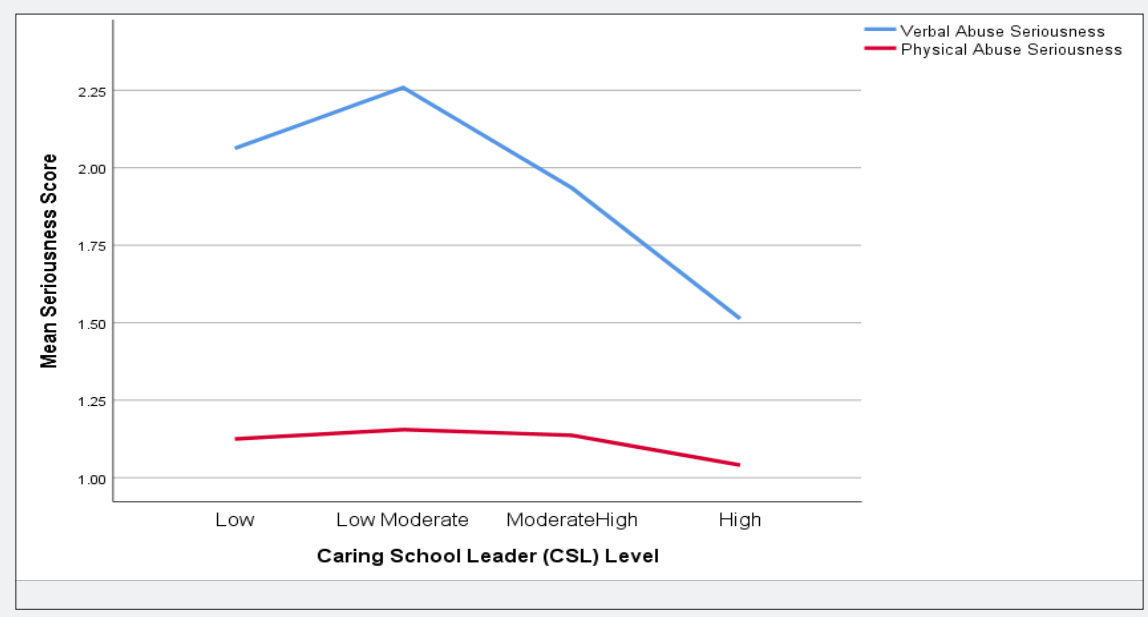

Figure 2: Variation in Teacher Abuse Scores According to reports of school CSL Level. Notes: Y axis scores range from 1 (Insignificant) to 3 (Serious).

\section{Discussion}

This study sought to identify and evaluate the significance of the prevailing levels of CSL in the SA school system according to accepted benchmarks. The distribution of respondents per province was uneven, with the majority coming from two SA provinces, namely the Free State $(n=310)$ and the Western
Cape $(n=165)$. Consequently, the results reported here can only be regarded as indicative and cannot be generalised to all SA teachers and schools in all provinces. However, a pattern of dysfunction associated with suboptimal CSL (and associated low PSC) has emerged from this investigation, which is consistent with other studies amongst Australian and SA teachers [23] 


\section{Psychology and Behavioral Science International Journal}

and is also consistent with other studies investigating the South African education scene that have been reviewed [9]. All the study hypotheses were supported by the results from this study. Taken together, the study identifies suboptimal CSL and PSC levels being reported in all participating provinces across SA, with PSC levels being worse in Rural, Government and Secondary schools. Low CSL values are shown to be consistently associated with higher levels of dysfunctional behaviour, such as Bullying, Perseverant Commitment and Absenteeism. In addition, low CSL values were associated with important maladaptive outcomes, including Work-Affected Poor Health and higher levels of Teacher Abuse by students and parents. In contrast, higher levels of CSL were associated with higher Engagement, Affective Commitment and less Cynicism.

In conclusion, Table 8 below shows the analysis of suboptimal PSC levels reported in schools across all the Provinces surveyed. The data shown in Table 8 indicates that, across all the Provinces surveyed, up to $80 \%$ (Gauteng) of respondents reported PSC levels at their schools that may place them at high risk of developing poor health, job strain and depression. Given the close relationship of PSC and CSL, it suggests that the need for attention to this construct of CSL, however it might be formulated, is high. The working environment of an unacceptably high proportion of SA teachers places them 'at risk' of health problems.

Table 8: Distribution of Maladaptive PSC Scores by Province According to Bailey Scores.

\begin{tabular}{|c|c|c|c|c|c|}
\hline Province & PSC Danger to Health & Mean & $\mathbf{N}$ & Maximum & $\%$ of Total \\
\hline \multirow{4}{*}{ Eastern Cape } & High & 15.5247 & 27 & 36.67 & $67.5 \%$ \\
\hline & Low & 39.1667 & 3 & 40.83 & \\
\hline & No Danger to Health & 48.7500 & 10 & 56.67 & \\
\hline & Total & 25.6042 & 40 & 56.67 & \\
\hline \multirow{4}{*}{ Free State } & High & 17.1855 & 212 & 36.67 & $68.4 \%$ \\
\hline & Low & 38.7083 & 20 & 40.83 & \\
\hline & No Danger to Health & 50.6090 & 78 & 60.00 & \\
\hline & Total & 26.9839 & 310 & 60.00 & \\
\hline \multirow{4}{*}{ Gauteng } & High & 16.0972 & 60 & 36.67 & $82 \%$ \\
\hline & Low & 39.2857 & 7 & 40.83 & \\
\hline & No Danger to Health & 49.6875 & 16 & 58.33 & \\
\hline & Total & 24.5281 & 83 & 58.33 & \\
\hline \multirow{4}{*}{ KwaZulu Natal } & High & 21.2000 & 25 & 36.67 & $65.8 \%$ \\
\hline & Low & 38.5417 & 4 & 40.83 & \\
\hline & No Danger to Health & 49.2593 & 9 & 59.17 & \\
\hline & Total & 29.6711 & 38 & 59.17 & \\
\hline \multirow{4}{*}{ Limpopo } & High & 19.4444 & 12 & 36.67 & $70.6 \%$ \\
\hline & Low & 39.1667 & 2 & 40.83 & \\
\hline & No Danger to Health & 50.8333 & 3 & 56.67 & \\
\hline & Total & 27.3039 & 17 & 56.67 & \\
\hline \multirow{4}{*}{ Mpumalanga } & High & 21.4583 & 8 & 36.67 & $72.7 \%$ \\
\hline & Low & 39.1667 & 1 & 39.17 & \\
\hline & No Danger to Health & 52.0833 & 2 & 56.67 & \\
\hline & Total & 28.6364 & 11 & 56.67 & \\
\hline
\end{tabular}




\section{Psychology and Behavioral Science International Journal}

\begin{tabular}{|c|c|c|c|c|c|}
\hline \multirow{4}{*}{ Western Province } & High & 19.2942 & 98 & 36.67 & $59.4 \%$ \\
\hline & Low & 39.4048 & 14 & 40.83 & \\
\hline & No Danger to Health & 49.1195 & 53 & 60.00 & \\
\hline & Total & 30.5808 & 165 & 60.00 & \\
\hline Total & High & 17.7696 & 442 & 36.67 & $66.5 \%$ \\
\hline & Low & 39.0196 & 51 & 40.83 & \\
\hline & No Danger to Health & 49.9025 & 171 & 60.00 & \\
\hline & Total & 27.6770 & 664 & 60.00 & \\
\hline
\end{tabular}

The findings of the significant inverse relationship between measures of fatigue and PSC levels (Table 4) suggest the potential for the effects on health to include reactive depression of uncertain outcome as demonstrated in the Winwood, et al. [32,33] study of 1600 Australian nurses. In considering the significance of PSC in the workplace experience of SA teachers, Hypotheses 2 and 3 , respectively, predicted that PSC levels would correlate positively with Affective Commitment, Morale and Engagement and negatively with Bullying, Cynicism, Absenteeism and Work-Affected Poor Health. The relationships shown in Table 4 confirmed this. Similarly, low PSC /CSL scores were associated with maladaptive outcomes, such as low Affective Commitment, Morale and Engagement, confirming Hypothesis 3.

These observations are important since such negative interactions can quickly create a mutually reinforcing downward loss spiral. Respondents were also asked to report on their experience of Abusive Behaviour from either students or parents (as distinct from bullying behaviour by colleagues). In SA, the Centre for Justice and Crime Prevention, DBE RSA and UNICEF (2015) in their National School Safety Framework (NSSF) document have acknowledged that schools are currently often characterised by violence, bullying and fear, impacting adversely on direct educational outcomes, as well as on the healthy socialisation and development of learners towards teachers. The reports of such maladaptive behaviour of students is confirmed by the study reports shown in Table 7, and Figures 2 confirms the correlation of this with prevailing PSC and CSL levels in the school as anticipated in Hypothesis 4.

The evaluation of various studies into the area undertaken by Bush and Glover [26] suggests that rural SA schools are underfunded and under-resourced compared to their urban counterparts. Likewise, it is frequently asserted that private schools enjoy higher levels of resourcing [34]. Accordingly, given the known association between resourcing and PSC, these findings were consistent with those of Garrick et al [23] that Australian teachers at greatest risk for psychological injury tended to be employed by schools in low socio-economic areas, and in schools with low PSC.

\section{Study Limitations}

The overall number of participants in the study was lower than hoped for. Consequently, it is acknowledged that the results reported here are indicative only, and that they cannot be generalised to all teachers, schools and provinces in SA. Furthermore, the cross-sectional, single-wave study design and correlational results mean that the causal relationships between the study variables cannot be established [35]. Finally, the study's reliance on participants' self-reporting might introduce the Common Method Bias [36] although several statisticians assert such problems are frequently overstated $[37,38]$.

\section{Conclusions and Recommendations}

Notwithstanding the acknowledged limitations of the study, the results form a consistent pattern, which suggests that the teaching environment and the teaching profession in SA face numerous significant challenges. Furthermore, these results are broadly consistent with previous studies of workplace PSC internationally, as well as PSC within the teaching profession of other nations [22]. PSC and CSL assessment within the overall SA teaching environment, as well as in individual SA provinces and different types of respondent schools indicates that most respondents are from schools are in a high-risk category to develop poor health, job strain and depression. Cross-linking of effects (i.e. meso-mediation), when applied to the SA teaching scene (see Dollard, et al., In Press), suggest increasing PSC awareness, particularly among school principals, is arguably a potentially significant way forward in mitigating the current suboptimal state of teacher health and efficiency outlined in the DBE reports and confirmed in this study. The very high correlation between PSC and CSL values across all the assessed constructs is notable and arguably points a way forward to resolving the many challenges faced by SA schools. Namely, that a focus on both selecting and training school principals on the crucial significance that their presence as a 'Caring Leader' within their schools creates. This role is arguably of greater significance at every level than the administrative and policy functions which so many principals become overly burdened by, to the detriment of their capacity to function fully in their most important role which this study clearly indicates. 


\section{Future Research}

This study's results are sufficiently consistent in the dysfunctional pattern they reveal within SA schools to suggest the importance of further, larger-scale investigations to be undertaken within all the SA provinces to confirm its findings. Furthermore, future studies should, where possible, determine the reasons for the observed differences between rural and urban, government and private schools, which this study data does not allow. Such further research would need to be better funded, resourced and developed than was possible in the current study to ensure a high response rate, and deeper penetration of the rural provinces. In the future, evolving international and SA legislation can be expected to mandate a much higher level of 'duty of care' upon employers to protect their employees from both psychological as well as physical injury, with severe penalties by way of successful and expensive work-related stress compensation claims resulting from a failure to do so [39-45].

\section{References}

1. Hall GB, Dollard MF and Coward J (2010) Psychosocial Safety Climate: Development of the PSC 12. International Journal of Stress Management 17: 353-383.

2. Whiteford HA, Sheridan J, Cleary CM (2005) The work outcomes research cost benefit (WORC) project: The return on investment for facilitating help seeking behaviour. Australian and New Zealand Journal of Psychiatry 39.

3. Castle P and Buckler S (2009) How to be a successful teacher. Thousand Oaks, CA, United States.

4. Johnson SM and Naidoo AV (2016) A psychoeducational approach for prevention of burnout among teachers dealing with HIV/AIDS in South Africa. AIDS Care 29: 73-78.

5. Kokkinos CM (2007) Job stressors, personality and burnout in primary school teachers. British Journal of Educational Psychology 77: 229243.

6. Schwarzer R, Hallum S (2008) Perceived teacher self-efficacy as a predictor of job stress and burnout: Mediational analyses. Applied Psychology 57: 152-171.

7. Siu OL, Cooper CL and Phillips DR (2014) Intervention studies on enhancing work well being, reducing burnout and improving recovery experiences among Hong Kong health care workers and teachers. International Journal of Stress Management 21: 69-84.

8. Milner K and Khoza H (2008) A comparison of teacher stress and school climate across schools with different matric success rates. South African Journal of Education 28: 155-173.

9. Bush T and Glover D (2016) School leadership and management in South Africa: findings from asystematic literature review. International Journal of Educational Management 30(2).

10. Cox T, Griffiths AJ, Barlow CA (2000) Organisational interventions for work stress. HSE Books, Subury, United Kingdom.

11. Dollard MF and Kang S (2007) Psychosocial Safety Climate measure. In: Work \& Stress Research Group UoSA (ed). Adelaide, South Australia.

12. Dollard M, Dorman C, Tuckey M (2017) Psychosocial safety climate (PSC) and enacted PSC for workplace bullying and psychological health problem reduction. European Journal of Work and Organizational Psychology 26: 844-857.

13. Zohar D (1980) Safety climate in industrial organizations: theoretical and applied implications. Journal of Applied Psychology 65: 96-102.

14. Dollard MF, Tuckey MM, Dormann C (2012) Psychosocial Safety Climate moderates the job demand-resource interaction in predicting workgroup distress. Accident Analysis and Prevention. 45: 694-704.

15. Winwood PC, Bowden R and Stevens F (2013) Psychosocial safety climate: Role and Significance in Aged Care. Occupational Medicine and Health Affairs 1: 1-5.

16. Law R, Dollard MF, Tuckey MR (2011) Psychosocial safety climate as a lead indicator of workplace bullying and harassment, job resources, psychological health and employee engagement. Accident Analysis \& Prevention 43: 1782-1793.

17. McTernan WP, Dollard MF and LaMontagne AD (2013) Depression in the workplace: An economic cost analysis of depression-related productivity loss due to job strain and bullying. Work and Stress 27: 321-338.

18. Ortega A, Christensen KB, Hogh A (2011) One-year prospective study on the effect of workplace bullying on long-term sickness absence. Journal of Nursing Management 19: 752-759.

19. Hogh A, Hoel H and Carneiro IG (2011) Bullying and employee turnover among healthcare workers: a three-wave prospective study. Journal of Nursing Management19: 742-751.

20. Bailey TS, Dollard, M F, McLinton S S Richards, P.A (2015 a) Psychological Safety Climate, Psychosocial and physical factors in the aetiology of musculoskeletal disorder symptoms and workplace injury compensation claims. Work \& Stress 29: 190-211.

21. Cropanzano R and Mitchell MS (2005) Social Exchange Theory; An interdisciplinary review. Journal of Management 31: 874-900.

22. Garrick, A, Mak, AS, Cathcart, S, Winwood, PC, Bakker, AB and Lushington, K (2014 a) Psychosocial safety climate moderating the effects of daily job demands and recovery on fatigue and work engagement. Journal of Occupational and Organizational Psychology, 87(4): 694-714.

23. Garrick A, Winwood PC, Mak AS (2014 b) Prevalence and Organisational Factors of Psychological Injury Among Australian School Teachers. Australasian Journal of Organisational Psychology 7: 1-12.

24. Pretorius S and de Villiers E (2009) Educators Perceptions of School Climate and Health in selected Primary Schools South African Journal of Education 29(1) 88-99.

25. Southworth G (2002) Instructional Leadership in Schools: Reflections and empirical evidence. School Leadership and Management 22(1) 7391.

26. Bush T and Glover D (2014) School leadership models: What do we know? School Leadership and Management 34(5)1-19.

27. Beck, LG (1994) Reclaiming Educational Administration as a Caring Profession. Teachers College Press, New York, United States.

28. Beck, LG and Murphy, J (1993) Understanding the Principalship: Metaphorical Themes, 1920's-1990's. Teachers College Press, New York, United States.

29. Lyman, L.L. (2000) How do they know you care? The Principal's Challenge. Teachers College Press, New York, United States.

30. Hargreaves, A (1998) The emotional practice of teaching. Teaching and Teacher Education 14(8): 835-854. 
31. Bailey TS, Dollard MF and Richards PA (2015) A national standard for psychosocial safety climate (PSC): PSC 41 as the benchmark for low risk of job strain and depressive symptoms. J Occup Health Psychol 20: 15-26.

32. Winwood PC, Winefield AH, Dawson D (2005) Development and Validation of a Scale to Measure Work-Related Fatigue and Recovery: The Occupational Fatigue Exhaustion Recovery scale (OFER). Journal of Occupational and Environmental Medicine 47(6): 594-606.

33. Winwood PC, Lushington K and Winefield AH (2006) Further development and validation of the Occupational Fatigue Exhaustion Recovery (OFER) scale. Journal of Occupational \& Environmental Medicine 48(4): 381-389.

34. Wilde, RJ, Green, F, Taylor-Gooby, P and Wiborg, S (2016) Private Schools and the Provision of 'Public Benefit'. Journal of Social Policy 45(2): 305-323.

35. Hakanen JJ, Bakker AB and Shaufeli WB (2006) Burnout and Work Engagment among teachers. Journal of School Psychology 43: 495-513.

36. Schaller TK, Patil A and Malhotra NK (2015) Alternative techniques for assessing common method variance. An analysis of the Theory of Planned Behaviour research. Organisational Research Methods 18: 177-206.

37. Crampton SM and Wagner III JA (1994) Percept-percept inflation in microorgnanisational research: An investigation of prevalence and effect. Journal of Applied Psychology 79: 67-76.

38. Doty DH and Glick WH (1998) Common methods bias: Does Common
Method variance really bias results? Organisational Research Methods 1:374-406.

39. Winwood PC, Tuckey MR, Peters R (2009) Identification and measurement of work-related psychological injury: piloting the psychological injury risk indicator among frontline police. Journal of Occupational \& Environmental Medicine51: 1057-1065.

40. Baptiste I (2001) Educating lone wolves: Pedagogical implications of human capital theory. Adult Education Quarterly 51(3): 184-201.

41. Bova N, De Jonge J and Guglielmi D (2015) The Demand-Induced Strain Compensation Questionnaire: A Cross-national Validation Study. Stress Health 31: 236-244.

42. Dollard MF and Bakker AB (2010) Psychosocial safety climate as a precursor to conducive work environments, psychological health problems, and employee engagement. Journal of Occupational and Organizational Psychology, 83: 579-599.

43. Maslach C, Jackson SE and Leiter MP (1981) Maslach Burnout Inventory. Consulting Psychologists Press, MBI, Palo Alto , CA, United States.

44. Meyer JP and Allen NJ (1991) A three component conceptualisation of organisational committment Human Resource Management Review 1: 61-89.

45. Schaufeli W, Bakker AB (2006) The measurement of Work Engagement with a short questionnaire; A Cross National study. Educational and Psychological Management 66(4): 701-716.

\section{Your next submission with Juniper Publishers will reach you the below assets}

- Quality Editorial service

- Swift Peer Review

- Reprints availability

- E-prints Service

- Manuscript Podcast for convenient understanding

- Global attainment for your research

- Manuscript accessibility in different formats

( Pdf, E-pub, Full Text, Audio)

- Unceasing customer service

Track the below URL for one-step submission https://juniperpublishers.com/online-submission.php 